\title{
Differential Responses of Nematode Communities to Soybean Genotypes Resistant and Susceptible to Heterodera glycines race 3
}

\author{
Dinaelia Iva das Neves \& Shiou Pin Huang \\ Departamento de Fitopatologia, Universidade de Brasília, CEP 70910-900, Brasília, DF
}

(Accepted for publication on 09/08/2004)

Corresponding author: Shiou Pin Huang

NEVES, D.I. \& HUANG, S.P. Differential responses of nematode communities to soybean genotypes resistant and susceptible to Heterodera glycines race 3. Fitopatologia Brasileira 30:21-25. 2005.

\begin{abstract}
Heterodera glycines and Helicotylenchus dihystera were the two most abundant plant-parasitic nematodes found in two $H$. glycines race 3-infested fields, Chapadão do Céu, MS and Campo Alegre, MG. These fields had been planted with resistant (R) and susceptible (S) plants to cyst nematodes. In the first field, soybean (Glycine max) FT-Cristalina (S) was susceptible to H. glycines but resistant to H. dihystera, while GOBR93 122243 (R) was just the opposite. In the second field, M-Soy 8400 (R) was more resistant to the spiral nematode than M-Soy8411 (S), but the resistance to the cyst nematode was not different between the two genotypes. The total abundance of nematodes was not different between the susceptible and resistant plants in the two fields, suggesting that $H$. dihystera and/or bacterial feeders and other trophic groups replaced the reduced abundance of the cyst nematodes in resistant plants. Bacterial feeders acted as a compensatory factor to plant-parasitic nematodes in ecological function. The populations of fungal feeders were higher in GOBR93 122243 (R) than in susceptible FT-Cristalina (S) in Chapadão do Céu, but lower in M-Soy 8400 (R) than in M-Soy 8411 (S) in Campo Alegre. This is being attributed to the different periods of soil samplings that were made at the florescent period in the first field, and at the final growing cycle in the second field. Only four nematodes, $H$. glycines, $H$. dihystera, Acrobeles sp. and Panagrolaimus sp. dominated the nematode resistant community GOBR93 122243 (R) in Chapadão do Céu, but dominance was shared by ten genera in Campo Alegre, which explains why the five diversity indexes (S, d, Ds, H' and T) were higher in resistant plants than in susceptible plants in field two.
\end{abstract}

Additional keywords: nematode community, Heterodera glycines, Helicotylenchus dihystera, Glycine max.

\section{RESUMO}

Reação diferenciada da comunidade de nematóides a genótipos de soja resistentes e suscetíveis a Heterodera glycines raça 3

Heterodera glycines e Helicotylenchus dihystera foram os dois fitoparasitas mais abundantes em dois campos localizados no estado de Goiás, Chapadão do Céu e Campo Alegre, infestados por H. glycines raça 3, onde foram plantadas cultivares suscetíveis (S) e resistentes (R). No primeiro campo, 'FT-Cristalina' (S) foi suscetível a H. glycines e resistente a H. dihystera. Porém, reação contrária ocorreu com 'GOBR93 122243' (R). No segundo campo, 'M-Soy 8400' (R) foi mais resistente ao nematóide espiralado do que 'M-Soy 8411' (S), mas a resistência ao nematóide do cisto não foi diferente entre esses dois genótipos. A abundância total não foi diferente entre os genótipos suscetíveis e resistentes, sugerindo que $H$. dihystera e/ou os outros grupos tróficos, especialmente os bacteriófagos, suplantaram a abundância reduzida do nematóide do cisto nos genótipos resistentes. Os bacteriófagos funcionaram como um fator compensativo aos fitoparasitas na função ecológica. A população de micófagos foi maior na 'GOBR93 122243' (R) do que na 'FT-Cristalina' (S) em Chapadão do Céu, mas menor na 'M-Soy 8400' (R) do que na 'M-Soy 8411' (S) em Campo Alegre, devido, possivelmente, aos diferentes períodos de amostragem: florescimento no primeiro campo, e final do ciclo de crescimento no segundo. Os quatros nematóides H. glycines, H. dihystera, Acrobeles sp. e Panagrolaimus sp. dominaram a comunidade de nematóides no primeiro campo, mas a dominância foi dividida por dez gêneros no segundo campo. Isto explica o porquê dos cinco índices de diversidade ( $\mathrm{S}$, d, Ds, H' e T) apresentarem maiores valores nas plantas resistentes do que nas suscetíveis no campo dois.

Palavras-chave adicionais: comunidades de nematóide, Heterodera glycines, Helicotylenchus dihystera, Glycine max.

\section{INTRODUCTION}

Soil nematode communities are characterized by multispecies, and high abundance, with five trophic groups (plant parasites, bacterial and fungal feeders, predator and omnivores) and different reproductive rates. All of these characteristics reflect on environmental changes by nematode taxa and other various indices. They are considered to be sensitive indicators for agricultural management (Linden, et al., 1994), see on an ecologically large-scale to influence different land-use systems (Freckman \& Ettema, 1993; Mattos, 1999; Jorge, 1999; Huang $\&$ Cares, 2000) and on a smaller scale in such things as same crop in rows and between rows (Freckman \& Huang, 1998; McSorley \& Frederick, 1996).

In the interaction of plant and nematodes, one resistance mechanism is attributed to the different compositions and 


\section{D.I. Neves \& S.P. Huang}

concentrations of allelochemics in root exudates that attract, repel, or kill nematodes (Veech, 1981). Beside these preinfectional resistant factors, it is also possible that different cultivars produce different root exudates, resulting in different contents of soil microflora which further affect the abundance of microbivorous nematodes that have been considered as beneficial organisms for enhancing plant growth nutritionally (Freckman \& Caswell, 1985). On the other hand, the ecological function of soil nematodes in ecosystems is considered to be an organic decomposer that releases nutrients in soil for feasible absorption by plant roots (Coleman et al., 1984). Plant parasites and bacterial feeders are the two dominant functional groups in most ecosystems (Freckman \& Caswell, 1985). Also, the abundance of Heterodera glycines Ichinohe, 1952 is expected to be dominant in susceptible genotypes and reduced in resistant genotypes. For this reason, two possible assumptions related to nematode communities were made: 1) Due to the reduced abundance of the cyst nematode in resistant plants, the total abundance of soil nematodes would be lower than in susceptible ones; and 2) this reduced abundance might be substituted by other plant-parasitic nematodes and/or by the other functional groups, resulting in total abundance remaning at the same level.

Therefore, the objectives of this study were to detect the structural changes of nematode communities in susceptible and resistant soybean [Glycine $\max (\mathrm{L}$.) Merril] genotypes, and to verify whether the reduced cyst nematode in resistant plants was substituted by other nematodes.

\section{MATERIALAND METHODS}

The experiment was conducted in two $H$. glycines race 3-infested soybean [GLycine $\max (\mathrm{L}$.) Merril] plantations, one at Fazenda Unigel, Chapadão do Céu, GO, and another at Mr. Ideo's farm, Campo Alegre, MG. The area at Chapadão do Céu was cultivated with line GOBR93 122243 and cultivar FTCristalina, respectively resistant and susceptible to the cyst nematode race 3 . Each was cultivated in eight plots $\left(2 \times 5 \mathrm{~m}^{2}\right.$ each) in a completely randomized design. Soil samplings were made in each plot at ten points in one zigzag line from 0 to 20 $\mathrm{cm}$ depth within the root zone by a 7-cm-diameter steel tube, and composed to make one sample for nematode extraction. In Campo Alegre, the experiment was set up in two separate but adjacent areas ( 0.5 ha each), one planted with line M-Soy 8400 and another with line M-Soy 8411, respectively resistant and susceptible to the cyst nematode race 3 . Soil samples at each area were collected from eight zigzag lines with five sampling points each by a steel tube at the same depth near the root zone. The samplings were made in February, the inflorescent phase, in Chapadão do Céu, and in April, the senescent period, in Campo Alegre. M-Soy 8400 was bred from Coker 6738 which was originally introduced from cultivar Peking (Silva, et. al., 2003), whereas GOBR93 122243 was from cultivar Hartwig. 'Peking' was one of the four different resistant sources (the other three are: Pickett, PI88788 and PI90763) being used for identifying 16 races (Riggs \& Schmitt, 1988), and 'Hartwig' was bred from the four resistant sources to have resistance to all races (Anand, 1992).

Nematodes from $100 \mathrm{~g}$ of soil samples were extracted by the method of fluctuation-sieving-centrifugation. By that, the soil was stirred in 21 of water, left unstirred for $60 \mathrm{~s}$, then passed through a 450 ìm-pore-opening screen and collected on a 44 ìm-opening screen. After the nematode suspensions had been centrifuged at 3,500 rpm $(1,307 \mathrm{~g})$ for $5 \mathrm{~min}$, their supernatants were discarded, and their sediments were added with one mole of sugar solution for further centrifugation at $1,500 \mathrm{rpm}(240 \mathrm{~g})$ for $1 \mathrm{~min}$. Nematodes from the supernatants were collected by a $10 \mathrm{im}$-opening screen, further killed by hot water, and fixed a $3 \%$ formalin solution. After counting the total number of nematodes in each sample, they were infiltrated through alcohol to glycerin (Seinhorst, 1959), and mounted on glass slides. All nematodes were identified to the genus level, and the data were transformed into parameters of abundance, trophic groups (plant parasite, bacterial and fungal feeders, predator and omnivore) and diversity (Simpson's and Shannon-Weaver's indexes, both index evenness, and trophic diversity), as done previouly (Gomes et. al., 2003). The values were submitted to ANOVA by the $\mathrm{SAS}^{\circledR}$ computer program.

\section{RESULTS}

There was no difference in total abundance between susceptible and resistant plants in the two experimental fields (Table 1). Thirty-five genera were identified from soils planted with 'FT-Cristalina' (S) and 31 genera with GOBR93 122243 (R) in Chapadão do Céu, whereas 24 genera identified from soils planted with 'M-Soy 8411' (S) and 29 genera with 'M-Soy 8400' (R) in Campo Alegre. In Chapadão do Céu, H. glycines, Helicotylenchus dihystera (Cobb) Sher, Acrobeles sp. and Panagrolaimus sp. dominated nematode communities with about $85 \%$ of total abundance in the two genotypes. The abundance of $H$. glycines was higher in 'FT-Cristalina' than in 'GOBR93 122243', but the populations of H. dihystera and Panagrolaimus sp. were higher in 'GOBR93 122243' than in 'FT-Cristalina', and that of Acrobeles sp. showed no difference in the two soybean genotypes. In Campo Alegre, H. glycines, H. dihystera, Acrobeles sp., Cephalobus sp., Paraxonchium sp. and Aphelenchus sp. were dominated nematode communities with abundance over $68 \%$, in which the abundance of H. dihystera and Acrobeles sp. was high in 'MSoy 8411', and that of Cephalobus sp., Paraxonchium sp. and Aphelenchus sp. was low in 'M-Soy 8400'. The abundance of soybean cyst nematodes was not different between the susceptible and resistant plants.

In Chapadão do Céu, the trophic diversity $(\mathrm{T})$ was higher in the resistant 'GOBR93 122243' than in the susceptible 'FTCristalina', whereas in Campo Alegre, the five diversity indexes ( $\mathrm{S}$, $\mathrm{D}, \mathrm{Ds}, \mathrm{H}$ ' and T) were higher in 'M-Soy 8400' than in 'M-Soy 8411'. The rest of the measurements did not differ (Table 2).

In Chapadão do Céu, the relative abundance of plant parasites and omnivores was higher in 'FT-Cristalina', whereas the population of bacterial and fungal feeders was higher in 
Differential responses of nematode communities to soybean genotypes resistant ...

TABLE 1 - Relative abundance (\%) of nematode genera associated with four soybean (Glycine max) genotypes susceptible (S) and resistant (R) to Heterodera glycines in Chapadão do Céuand Campo Alegre-GO

\begin{tabular}{|c|c|c|c|c|}
\hline \multirow{2}{*}{$\begin{array}{l}\text { Genus of } \\
\text { nematodes }\end{array}$} & \multicolumn{2}{|c|}{$\begin{array}{c}\text { Chapadão do Céu }^{1} \\
\end{array}$} & \multicolumn{2}{|c|}{ Campo Alegre $^{1}$} \\
\hline & $\begin{array}{c}\text { 'FT-Cristalina' } \\
\text { (S) }\end{array}$ & $\begin{array}{c}\text { 'GOBR93122243' } \\
\text { (R) }\end{array}$ & $\begin{array}{c}\text { 'M-Soy 8411' } \\
\text { (S) } \\
\end{array}$ & $\begin{array}{c}\text { 'M-Soy 8400' } \\
\text { (R) }\end{array}$ \\
\hline \multicolumn{5}{|l|}{ Plant parasite } \\
\hline Helicotylenchus & $17.67 \mathrm{~b}$ & $45.44 \mathrm{a}$ & $16.79 a$ & $1.7 \mathrm{~b}$ \\
\hline Heterodera & $51.87 \mathrm{a}^{*}$ & $9.24 b$ & 41.09 & 34.06 \\
\hline Trichodorus & $0 \mathrm{~ns}$ & 1.05 & 0 & 0 \\
\hline \multicolumn{5}{|l|}{ Bacterial feeder } \\
\hline Acrobeles & 10.16 & 14.71 & $14.71 \mathrm{a}$ & $9.17 b$ \\
\hline Alaimus & $0.48 b$ & $1.36 \mathrm{a}$ & 0.33 & 0.68 \\
\hline Cephalobus & 0.37 & 0 & $0 b$ & $9.61 \mathrm{a}$ \\
\hline Eucephalobus & 0.18 & 0 & $0 \mathrm{~b}$ & $4.61 \mathrm{a}$ \\
\hline Monhystera & 0.62 & 0.39 & 0.09 & 3.47 \\
\hline Panagrolaimus & $5.96 b$ & $14.74 \mathrm{a}$ & 0.38 & 0 \\
\hline Prismatolaimus & 0.73 & 2.29 & $0.99 b$ & $4.02 \mathrm{a}$ \\
\hline \multicolumn{5}{|l|}{ Fungal feeder } \\
\hline Aphelenchoides & $0.18 b$ & $1.09 \mathrm{a}$ & 0.14 & 0.38 \\
\hline Aphelenchus & 0.77 & 1.79 & 6.68 & 6.57 \\
\hline Ditylenchus & 0.22 & 0.31 & $3.06 \mathrm{a}$ & $0.23 b$ \\
\hline Tylenchus & 0.59 & 0.85 & 1.41 & 1.01 \\
\hline \multicolumn{5}{|l|}{ Predator } \\
\hline Aporcelaimellus & $2.13 \mathrm{a}$ & $0.54 b$ & 3.1 & 5.23 \\
\hline Crassolabium & 0.95 & 1.16 & 0.09 & 0 \\
\hline Discolaimium & 1.68 & 1.24 & 0.28 & 0.05 \\
\hline Discolaimoides & 0.04 & 0.04 & 0.23 & 1.25 \\
\hline Discolaimus & 0.18 & 0.08 & $0.05 b$ & $4.67 \mathrm{a}$ \\
\hline Paraxonchium & 0.37 & 0.12 & 9.4 & 7.93 \\
\hline Thonus & 1.61 & 1.51 & 0.61 & 0.65 \\
\hline \multicolumn{5}{|l|}{ Omnivore } \\
\hline Oriverutus & 0.4 & 0 & $\mathrm{Ob}$ & $2.74 \mathrm{a}$ \\
\hline Other ${ }^{2}$ & 2.84 & 4.46 & 0.57 & 3.67 \\
\hline Total abundance ${ }^{3}$ & $342 \mathrm{~ns}$ & 322 & $266 \mathrm{~ns}$ & 230 \\
\hline Total genera (no.) & 35 & 31 & 24 & 29 \\
\hline
\end{tabular}

${ }^{1} \mathrm{n}=8$, different letters in the same rows and field show significant difference at Tukey test $(p<0.05 \%)$.

2 "Others" indicate these rare nematodes, each with abundance $<1 \%$, including Pratylenchus ${ }^{1,2}$, Acrobeloides $^{1,4}$, Chronogaster $^{1}$, Cryptonchus ${ }^{4}$, Paraphanolaimus ${ }^{1}$, Plectus $^{1,2,4}$, Teratocephalus ${ }^{4}$, Diphtherophora ${ }^{2}$, Leptonchus $^{2}$, Prodorylaimium ${ }^{2}$, Coslenchus 3, Akrotonus $^{1,2,3,4}$, Indodorylaimus $^{2}$, Makatinus $^{1,2,3,4}$, Moshajia $^{1}$, Pungentus $^{1}$, Sicaguttur ${ }^{2}$, Tobrilus ${ }^{1,2}$, Dorylaimoides ${ }^{1,3,4}$, Enchodelus $^{1,2,3}$, Enchodorus $^{1,2}$, Eudorylaimus $^{1,4}$, Oxidirus $^{3}$. The numbers following genera indicate the presence of the nematode in Ft-Cristalina (1), GOBR93 122243 (2), M-Soy 8411 (3) and M-Soy 8400 (4).

${ }^{3}$ Number of nematodes/100 g of soil.

'GOBR93 122243'. In Campo Alegre, the population of bacterial feeders, predators and omnivores was lower, while those of plant parasites and fungal feeders were higher in 'M-Soy 8411' than in 'M-Soy 8400'.

\section{DISCUSSION}

In this experiment, $H$. glycines and $H$. dihystera were the two most important plant parasitic nematodes in the two experimental sites. In Chapadão do Céu, H glycines was more abundant than $H$. dihystera in 'FT-Cristalina' (52 vs. $18 \%$, respectively), but it was the opposite in 'GOBR93 122243' (9 vs. $45 \%$, respectively), indicating that FT-Cristalina was susceptible to $H$. glycines, but resistant to $H$. dihystera, whereas GOBR93 122243 was resistant to the cyst nematode but susceptible to the spiral nematode. Clearly, the reduced abundance of $H$. glycines in these resistant plants was substituted by the increased abundance of $H$. dihystera. In Campo Alegre, $H$. glycines showed no difference in abundance between 'M-Soy 8411' and 'M-Soy 8400' (41 and 34\%, respectively), but $H$. dihystera showed difference in abundance (16 and $1.7 \%$, respectively) between the two genotypes, demonstrating that the cyst-nematode resistance of 'M-Soy 8400 ' which was bred from 'Coker 6738' was not expressed, but the same soybean plants manifested their resistance to the spiral nematode. Above results indicate that the resistance of soybean to the two major plant-parasitic nematodes was from different sources. 
TABLE 2 - Diversity indexes and trophic groups related to nematode communities associated with four soybean (Glycine max) genotypes susceptible (S) or resistant (R) to Heterodera glycines in Chapadão do Céu- and Campo Alegre-GO

\begin{tabular}{|c|c|c|c|c|}
\hline \multirow[b]{2}{*}{ Measurement } & \multicolumn{2}{|c|}{ Chapadão do Céu* } & \multicolumn{2}{|c|}{ Campo Alegre* } \\
\hline & $\begin{array}{c}\text { FT-Cristalina' } \\
\text { (S) } \\
\end{array}$ & $\begin{array}{c}\text { 'GOBR93 122243' } \\
\text { (R) }\end{array}$ & $\begin{array}{c}\text { 'M-Soy 8411' } \\
\text { (S) }\end{array}$ & $\begin{array}{c}\text { 'M-Soy 8400' } \\
\text { (R) }\end{array}$ \\
\hline \multicolumn{5}{|l|}{ Diversity } \\
\hline No. of genera/sample (S) & $19.75 \mathrm{~ns}$ & 18.00 & $13.12 b$ & $17.63 \mathrm{a}$ \\
\hline Genus richness (d) & 7.40 & 6.80 & $5.01 b$ & $7.06 \mathrm{a}$ \\
\hline Shannon-Weaver's index (H') & 1.64 & 1.73 & $1.75 b$ & $2.14 \mathrm{a}$ \\
\hline Evenness of $\mathrm{H}\left(\mathrm{J}^{\prime}\right)$ & 0.55 & 0.60 & 0.69 & 0.75 \\
\hline Simpson's index (Ds) & 0.67 & 0.72 & $0.75 b$ & $0.81 \mathrm{a}$ \\
\hline Evenness of Ds (Es) & 0.95 & 0.94 & 0.81 & 0.87 \\
\hline Trophic diversity index $(\mathrm{T})$ & $1.82 b^{*}$ & $2.14 \mathrm{a}$ & $2.57 \mathrm{~b}$ & $3.21 \mathrm{a}$ \\
\hline \multicolumn{5}{|l|}{ Trophic group } \\
\hline Plant parasite (PP) $(\%)$ & $70.08 \mathrm{a}$ & $55.93 \mathrm{~b}$ & $56.83 a$ & $35.76 b$ \\
\hline Bacterial feeder $(\mathrm{BF})(\%)$ & $19.56 \mathrm{~b}$ & $34.22 \mathrm{a}$ & $17.07 \mathrm{~b}$ & $32.21 \mathrm{a}$ \\
\hline Fungal feeder (FF) $(\%)$ & $1.80 \mathrm{~b}$ & $4.32 \mathrm{a}$ & $11.31 \mathrm{a}$ & $8.19 b$ \\
\hline Predator $(\mathrm{PR})(\%)$ & 7.47 & 5.54 & $14.50 \mathrm{~b}$ & $20.99 a$ \\
\hline Omnivore (OM) (\%) & $1.10 \mathrm{a}$ & $0.00 \mathrm{~b}$ & $0.29 b$ & $2.85 \mathrm{a}$ \\
\hline
\end{tabular}

* Different letters in the same row and field show significant difference at Tukey test $(\mathrm{p}<0,05 \%)$

In Chapadão do Céu, the resistant 'GOBR93 122243' decreased $H$. glycines population but increased those of $H$. dihystera and Panagrolaimus sp., as compared with the susceptible 'FT-Cristalina'. In contrast, the communities in Campo Alegre were dominated by seven nematodes $(H$. glycines, $H$. dihystera, Acrobeles sp., Aphelenchus sp. Ditylenchus sp. Aporcelaimellus sp. and Paraxonchium sp.) in susceptible 'M-Soy 8411 ' with $94 \%$ of abundance, but the dominance was shared by nine nematodes besides $H$. glycines (Acrobeles sp., Cephalobus sp., Eucephalobus sp., Monhystera sp., Prismatolaimus sp., Aphelenchus sp., Aporcelaimellus sp., Discolaimus sp., and Paraxonchium sp.) in resistant 'M-Soy 8400 ' with about $90 \%$ of abundance. The above results explain why only the $\mathrm{T}$ was higher in resistant plant than in susceptible plants in Chapadão do Céu, whereas five diversity indexes ( $\mathrm{S}$, $\mathrm{d}$, Ds, H' and T) were higher in resistant plants than in susceptible plants in Campo Alegre. The total abundance was no different between the susceptible and resistant plants in the two fields. Hence, this suggests that the spiral nematode and/or the other trophic groups had replaced the reduced abundance of $H$. glycines in the resistant plants.

Beside the diversity, the trophic structure in nematode communities was also different in the soils planted with resistant and susceptible plants. In the two experimental fields, the sum of relative abundance of plant parasites and bacterial feeders were almost the same level in both genotypes $(90.34 \%$ at 'FT-Cristalina' vs. $92.39 \%$ at 'GOBR93 122243', and $74.79 \%$ at line 'M-Soy 8411 ' vs. $79.23 \%$ at line 'M-Soy 8400 '). But the soil with susceptible plants possessed higher populations of plant parasites and lower populations of bacterial feeders, as compared with the resistant plants. Plant parasites and bacterial feeders are commonly dominant functional groups in nematode communities (Freckman \& Caswell, 1985), and play the major role of soil nutrient mineralization in ecosystems (Yeates \&
Coleman, 1982; Ingham, et al., 1985). This result hints that there was a defined amount of relative abundance for plant parasites and bacterial feeders to function in a defined system, with both functional groups acting in a compensatory manner, one increasing while the other decreased.

Gomes et al. (2003) reported that the population of fungal feeders increased at the final growing cycle of soybean because the root tissue was in decomposition. McSorley \& Frederick (1996) also showed that the abundance of plant parasites was slightly higher in the old soybean plants. In this experiment, soil samplings were made at the florescent period in the field of Chapadão do Céu, and at the final growing cycle in the field of Campo Alegre. The different sampling period may explain why the abundance of the fungal feeders and plant parasites was higher in the soil of Campo Alegre than in the soil of Chapadão do Céu. On the other hand, the abundance of predators and omnivores was higher (18.99\% at line 'M-Soy 8411' and 16.48\% at line 'M-Soy 8400') in the experiment at Campo Alegre than in the experiment $(8.89 \%$ at 'FT-Cristalina' and $5.55 \%$ at 'GOBR93 122243') at Chapadão do Céu, which may be related to the high and low abundance of bacterial feeders, relatively, in the two fields, supposing that the bacterial feeders could be prey to the two functional groups.

In conclusion, some key nematodes and trophic groups in nematode communities can differentiate well between soybean-cyst-resistant and -susceptible plants in the two experimental fields. Soybean reacted to $H$. glycines and to $H$. dihystera in different ways. The total abundance was no different in the resistant and susceptible plants in the two fields, suggesting that the spiral nematode and/or the other trophic groups, especially bacterial feeders, replaced the reduced abundance of the cyst nematode in the resistant plants. Bacterial feeders acted as a compensatory factor to plantparasitic nematodes in ecological function. 
Differential responses of nematode communities to soybean genotypes resistant ...

\section{LITERATURE CITED}

ANAND, S.C. Registration of Hartwig soybean. Crop Science 32:1069-1070. 1992.

COLEMAN, D.C., COLE, C.V. \& ELLIOTT, E.T. Decomposition, organic matter turnover, and nutrient dynamics in agroecosystems. In: R. Lowrance, B.R. Stinner \& G.J. House (Eds.), Agricultural Ecosystems. Unifying Concepts. 1984. pp.83-104.

FRECKMAN, D.W. \& CASWELL, E.P. The ecology of nematodes in agroecossystems. Annual Review of Phytopatology 23:275-295. 1985.

FRECKMAN, D.W. \& ETTEMA, C.H. Assessing nematode community in agroecosystems of various human intervention. Agriculture Ecosystem Environmental 45:239-261. 1993.

FRECKMAN, D.W. \& HUANG, S.P. Response of the soil nematode community in a shortgrass steppe to long-term and short-term grazing. Applied Soil Ecology 9:39-44. 1998.

GOMES, G.S., HUANG, S.P. \& CARES, J.E. Nematode community, trophic structure and population fluctuation in soybean fields. Fitopatologia Brasileira 28:258-266. 2003.

HUANG, S.P. \& CARES, J.E. The nematode community as a bioindicator to characterize five different landuse systems in two Brasilian tropical states, Rondônia and Acre. Tropical Soil Biology and Fertility TSBF Report 1997-1998, Nairobi. 2000. (Abstract).

INGHAM, R.E., TROFYMOOW, J.A., INGHAM, E.R. \& COLEMAN, D.C. Interactions of bacteria, fungi, and their nematode grazers: Effects on nutrient cycling and plant growth. Ecological monographs 55:19-140. 1985.

JORGE, C.L. Comunidade de nematóides em sistemas de plantio direto e convencional de soja, e em rotação com soja e milho. Tese de Mestrado Universidade de Brasília, DF. 1999.

LINDEN, D.R., HENDRIX, P.F., COLEMAN, D.C. \& VAN VLIET, P.C.J. Faunal indicators of soil quality. Soil Science 35:91-106. 1994.

MATTOS, JK. DE ABREU. Caracterização das comunidades de nematóides em oito sistemas de uso da terra nos cerrados do Brasil central. (Tese de doutorado). Depto. de Fitopatologia da Universidade de Brasília. 1999.

MCSORLEY, R. \& FREDERICK, J.J. Nematode community structure in rows and between rows of a soybean field. Fundamental and Applied Nematology 19:251-261. 1996.

RIGGS, R.D. \& SCHMITT, D.P. Complete characterizaton of the race scheme for Heterodera glycines. Journal of Nematology 20:392395.1988 .

SEINHORST, J.W. A rapid method for the transfer of nematodes from fixative to anhydrous gylcerine. Nematologica 4:67-69. 1959.

SILVA, J.F.V., DIAS, W.P., ASMUS, G.L. \& CARNEIRO, G.E.S. Manejo integrado de nematóides na cultura da soja. Fitopatologia Brasileira 28:S30-S34. 2003. (Resumo)

VEECH, J.A. Plant resistance to nematodes. In: Plant parasitic nematodes, vol 3, Zuckerman, B.M. \& Rohde, R.A. (Eds.). Academic Press, New York. 1981.

YEATES G.W. \& COLEMAN, D.C. Nematodes in decomposition. Freckman, D.W. (Ed.) Nematodes in soil ecosystems. Austin, TX: University of Texas. 1982. pp.55-80. 